\title{
The Effect of Guided Inquiry Learning Model to the Metacognitive Ability of Primary School Students
}

\author{
${ }^{1}$ Intan Dwi Hastuti, ${ }^{1}$ Yuni Mariyati, ${ }^{2 *}$ Sutarto, ${ }^{3}$ Chairun Nasirin \\ ${ }^{1}$ Elementary School Teacher Education Study Program, Universitas Muhammadiyah \\ Mataram, Jl. KH. Ahmad Dahlan No 1 Pagesangan, Mataram 83115, Indonesia \\ ${ }^{2}$ Mathematics Education Department, Faculty of Science, Engineering, and Applied Science, \\ Mandalika University of Education (UNDIKMA). Jl. Pemuda No. 59A, Mataram, 83125, \\ Indonesia. \\ ${ }^{3}$ Department of Health Administration, Sekolah Tinggi Ilmu Kesehatan (STIKES) Mataram, \\ J1. Swakarsa III, Sekarbela, Kekalik Jaya, Mataram, 83115, Indonesia \\ *Corresponding Author e-mail: sutarto@ikipmataram.ac.id
}

Received: May 2020; Revised: June 2020; Published: June 2020

\begin{abstract}
This study aimed at analyzing the effect of guided inquiry learning to the metacognitive ability of primary school students on the material of Least Common Multiple (KPK) and Greatest Common Divisor (FPB). The type of study was a mixed-method using quantitative and qualitative methods. There were 55 students of $4^{\text {th }}$ grade used as the subjects of study. Two learning models were compared, namely guided inquiry learning model and conventional learning model. The students' metacognitive ability was measured by means of problem-solving test on the material of Least Common Multiple $(K P K)$ and Greatest Common Divisor $(F P B)$. The quantitative analysis data used descriptive and inferential statistical tests. According to the results of data analysis, it was discovered that the t-test of sig (2-tailed) from the independent samples t-test of post-test was $0,00(p=<0,05)$; this indicated that there was a significant difference on it. This showed that there was a difference of students' metacognitive ability for both classes in solving the problems of Least Common Multiple $(K P K)$ and Greatest Common Divisor $(F P B)$ after the guided inquiry learning was implemented. Consequently, it can be concluded that there is a significant effect on the implementation of guided inquiry learning model to improve the students' metacognitive ability in solving the material problems of Least Common Multiple $(K P K)$ and Greatest Common Divisor $(F P B)$.
\end{abstract}

Keywords: Guided inquiry, Metacognitive ability, Primary school

How to Cite: Hastuti, I., D., Mariyati, Y., Sutarto, S., \& Nasirin, C. (2020). The Effect of Guided Inquiry Learning Model to the Metacognitive Ability of Primary School Students. Prisma Sains: Jurnal Pengkajian Ilmu dan Pembelajaran Matematika dan IPA IKIP Mataram, 8(1), 37-45. doi:https://doi.org/10.33394/j-ps.v8i1.2615

https://doi.org/10.33394/j-ps.v8i1.2615

Copyright $\odot$ 2020, Hastuti et al This is an open-access article under the CC-BY License. (c) () ()

\section{INTRODUCTION}

Students' metacognitive ability is one of indicators which determines the achievement of learning objectives. The involvement of metacognitive ability becomes one of important components on the learning activities since it can encourage high level of thinking ability (Kuzle, 2013; Biryukov, 2014; Wismath, Orr, \& Good, 2014). Metacognition is one part of high level of thinking ability which covers up understanding, analysis, and control of cognitive process (Dorr \& Perels, 2019; Flavell, Miller, \& Miller, 2002). Metacognition also can be defined as an ability to think what has been thought that covers up three activities i.e. awareness, regulation and evaluation (Hastuti, Nusantara, Subanji, \& Susanto, 2016). Metacognition involvement can help the students to solve problems since it can regulate the students' mental processes more effectively (Kim, Park, Moore, \& Varma, 2013).

Based on the results of study, it revealed that metacognitive abilities develop along with the age and uniquely this development takes place continuously (Stel \& Veenman, 2014). Thus, 
it is feasible to be analyzed about how to cause to emerge the student' metacognitive as the key aspect of independent learning for the initial stage, (Winne \& Hadwin, 2008). Moreover, Tarrant \& Holt (2017) in his book explain how to develop a metacognitive approach to primary school students. The students will have metacognitive ability if the students are accustomed to being involved in the metacognitive ability since they ware in the low class. Even developing countries, including Indonesia, have established policies where the metacognitive aspect becomes an important component in the standard competency of graduates of primary education (Minister of Education and Culture Regulations No 20 of 2016).

Previous study had revealed that the students' metacognitive skill in Indonesia is still in the lowest level (Prayitno, 2011; Suratno, 2009; Hastuti, Nusantara, Subanji, \& Susanto, 2016). Even the metacognitive abilities of primary school teacher candidates are still at a low level (Hastuti \& Haifaturrahmah, 2018). In fact, it is very sad since the metacognitive activity is a strong indicator of a person's cognitive development and determinant in achieving the learning goals. It is feared that the low metacognitive abilities in primary schools will have an impact on the low metacognitive abilities for the next level of education so that this problem needs to be sought for a solution.

A learning activity which designed using teacher-centered becomes one of factors that causes low of students' metacognitive ability and the learning emphasizes on the cognitive aspect. Additionally, the students are only involved on the routine items or not problem-solving items, so that the routine items have not been able to train the students to think at a high level. Teacher-centered learning habits are believed to produce passive students; hence, there is no involvement of students' metacognitive activities (Rahmat \& Chanunan, 2018). Furthermore, metacognition is closely related to problem-solving, of which metacognition arises when someone encounters an unknown problem, uncertainty, question, or dilemma (King, Goodson, \& Rohani, 1993).

Student-centered learning is one of solutions to improve the students' metacognitive ability i.e. inquiry learning model. Inquiry learning refers to a constructivism paradigm, where the students construct their own knowledge actively. The activities of inquiry learning are designed to resemble the activity of a scientist, where the students are involved to question, analyze ideas, design strategies, and discuss the results and the meaning of the results (Ellwood \& Abrams, 2018). Through this inquiry learning, the students construct their own knowledge actively so that the learning outcomes desired can be reached. On the inquiry learning activities, the students are involved on the activities that basically are open, student-centered, and directly based on the real-life problems. The inquiry learning is considered as a learning that comes when the students construct their understanding about new information by relating them with previous knowledge and the students' experience; this also plays important role in the inquiry learning activities (Rooney, 2009).

The inquiry learning is divided into three types, 1) structured inquiry, 2) guided inquiry, and 3) open inquiry. Guided inquiry learning is suitable for the primary school students since the students do not have much experiences in the inquiry learning (Suastra, 2017; Margunayasa., et al; 2018). The guided inquiry learning emphasizes on the importance of discovery processes by the students. There are six stages of guided inquiry learning i.e. 1) orientation, 2) problem formulation, 3) hypothesis determination, 4) data collection, 5) verification of results/hypothesis testing, and 6) drawing the conclusions.

Previous study had proven that inquiry-based learning can also improve the students' critical thinking ability (Thaiposri \& Wannapiroon, 2015; Prayogi, Yuanita, \& Wasis, 2018). Moreover, a study conducted by Ergul et al. (2011) also showed that the use of guided inquiry learning can significantly improve the ability and science process behavior of primary school students. The inquiry learning model has been quite popular in playing an important role to support higher order thinking skills in various fields, especially in science and mathematics (Hayes, 2002; Rooney, 2009; Towers, 2010). There are a lot of researchers who believed that the main goal of education is to grow a high level of thinking and the high level of thinking is 
one of important elements for the life success (Gough, 1991; Zohar, 2001; Sousa, 2008). The inquiry learning can also assist the students to develop their metacognitive ability (Kuhlthau, 2010; Seraphin., et al, 2012). Even though there are a lot of studies which investigate about the effect of guided inquiry learning to the high level of thinking ability including of metacognition, yet those studies are limited and do not investigate on the effect of guided inquiry learning to the metacognitive ability of primary school students. Furthermore, this study will give valuable contribution for the literature of mathematics education, especially on the primary school about the implementation of guided inquiry learning to the metacognitive ability. In this study, the researcher tries to analyze the difference of metacognitive ability between the primary school students who learn by means of guided inquiry learning and the students who learn by means of conventional learning model.

\section{METHOD}

The $5^{\text {th }}$ grade students of State Primary School of 13 Ampenan in Mataram City, West Nusa Tenggara, Indonesia were used as the population of this study. Two classes were chosen randomly for this study, in which it covered up one experimental class consisted of 28 students; they were taught using guided inquiry learning and the control class that consisted of 27 students, of which students were taught using a conventional learning model.

This study used a combination method of quantitative and qualitative (mixed-method). Quantitative method was used to analyze the data taken from the metacognitive ability test of primary school students after being implemented using guided inquiry learning. Then, qualitative method was implemented to analyze the data taken from the observation both of during the class learning and also group discussion, students' test results, and interview with the students who were chosen to dig up more information about their metacognitive ability. To discover deeply about the effect of guided inquiry learning, all of the students on the experimental and control groups were observed and interviewed about their processes in solving the problems of Least Common Multiple $(K P K)$ and Greatest Common Divisor $(F P B)$.

The instruments used in this study covered up Lesson Plan $(R P P)$, student worksheet, mathematical problem-solving test using the material of Least Common Multiple $(K P K)$ and Greatest Common Divisor $(F P B)$, and interview. The mathematical problem-solving test was used to collect the data of students' metacognitive ability. The problems of $K P K$ dan $F P B$ consisted of questions that integrated with the indicators of metacognitive ability i.e. planning, observing, and evaluation (Krathwohl, 2002). The indicators and description of metacognitive ability could be seen in the Table 1 .

Table 1. The Indicators and Description of Metacognitive Ability

\begin{tabular}{|c|c|c|}
\hline No. & Indicators & Description \\
\hline 1 & Plan & $\begin{array}{l}\text { - } \quad \text { Established the goals (P1) } \\
\text { - } \quad \text { Utilized relevant resources (P2) } \\
\text { - } \quad \text { Chose appropriate strategies (P3) }\end{array}$ \\
\hline 2 & Evaluation & $\begin{array}{l}\text { - Determined someone's understanding level (E1) } \\
\text { - How to choose appropriate strategies (E2) }\end{array}$ \\
\hline 3 & Monitoring & $\begin{array}{l}\text { - Checked someone's progress (M1) } \\
\text { - Chose appropriate strategies of improvement when the } \\
\text { strategy chosen did not work. (M2) }\end{array}$ \\
\hline
\end{tabular}

The metacognitive ability rubric consisted of seven scales (0-7) that covered up: (1) answers in their own words, (2) coherent sequence of answers, (3) grammar, (4) reason (analysis/evaluation, creation), and (5) answers (true/lacking/not really/blank) (Corebima, 2009).

Furthermore, the experimental design of this study was by preparing two group of classes, namely experimental and control classes using the design shown in the Table 2. 
Table. 2 Equivalent pre-test and post-test control group design

\begin{tabular}{lllll}
\hline Group & $\mathrm{n}$ & Pre test & Treatment & Pos test \\
\hline A & 28 & O1 & X & O2 \\
B & 27 & O3 & - & O4 \\
\hline
\end{tabular}

The Table 2 showed that A was the experimental group who implemented the guided inquiry learning, and B represented the control group who implemented the conventional learning. $\mathrm{O} 1$ and $\mathrm{O} 3$ were two groups that were in the similar metacognitive ability and those were tested using pre-test. $\mathrm{O} 2$ was the results of experimental group, while the $\mathrm{O} 4$ was the result of the control group. in this study, the effect of treatment was analyzed through the t-test.

The experiment had been carried out in 6 meetings, not including pre-test and post-test. The first stage was to prepare two class groups: the experimental class and the control class. Class A was an experimental group, in which the guided inquiry learning was implemented, while the Class B functioned as a control group taught by a conventional method. The second stage was to give pre-test for both groups. The third stage was the validation process. There were two mathematics education experts who validated the plans to implement the guided inquiry learning, the student worksheets, and pre-test and post-test questions that contained the problem-solving of the $K P K$ and $F P B$. The fourth stage was the treatment process. In this stage, the researcher had a role as a teacher. In the experimental class, the students were involved in guided inquiry learning activities. Meanwhile, in the control class, the students were taught using a conventional method. Providing a post-test was the fifth stage. In this stage, the students' metacognitive ability was analyzed.

Problem-solving questions about the $K P K$ and $F P B$ were given to the students of experimental and control groups during the pre-test and post-test. The qualitative data were collected through unstructured interviews based on the students' work during the post-test. Statistical analysis was descriptive and inferential, in which it was used to analyze the quantitative data. The descriptive statistics was used to display the mean and the standard deviation, while the inferential statistics was independent sample t-test to test the effectiveness of guided inquiry learning between the experimental class and the control class (Hilton et. Al., 2004). The significance level used to compare the average scores of the experimental and control classes was the significance level of $5 \%$.

\section{RESULTS AND DISCUSSION}

The independent sample t-test was used to test the effectiveness of guided inquiry learning between the experimental and control classes. The data normality test was checked before further analysis was carried out. There were 55 students used as the respondents. As seen from the Table 3 and Table 4, the results of pre-test for the experimental and control classes were the same or there was no significant difference. This assessment referred to the assessment rubric to measure the metacognitive ability, in which the rubric was developed by Corebima (2009).

Table 3. The Results of Pre-Test and Average Scores Between the Control Class and Experimental Class

\begin{tabular}{lllll}
\hline Group & N & Mean & Std. Deviation & Std. Error Mean \\
\hline Experimental Class & 29 & 4.72 & 1.771 & .329 \\
Control Class & 28 & 4.39 & 1.707 & .323 \\
\hline
\end{tabular}

The average scores of experimental class were $4.72(\mathrm{SD}=1,771)$, while the control class was marked with the average scores of $4.39(\mathrm{SD}=1.707)$. The pre-test score difference between both groups was $[\mathrm{t}(55)=0.887, \mathrm{p}>0,05]$, it meant that it was not significant on the alpha level of .05. this indicated that both groups were equivalent before the treatment. 
Table 4. The Comparation of Pre-Test Scores of Experimental Class and Control Class Score Using the Independent Sample T-Test

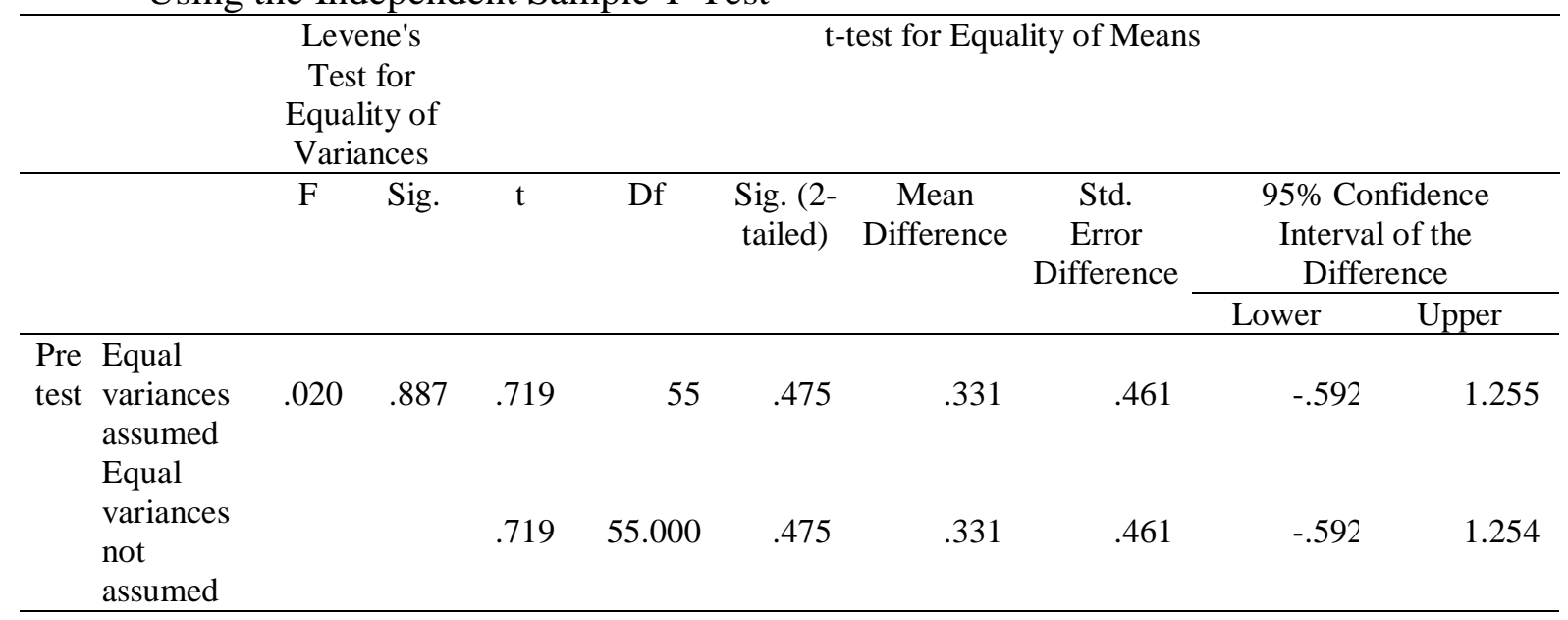

Table 5. The results of Post-Test and the Average Scores Between the Control Class and Experimental Class

\begin{tabular}{llcrr}
\hline Group & N & Mean & Std. Deviation & Std. Error Mean \\
\hline Experimental class & 29 & 8.59 & 1.991 & .370 \\
Control class & 28 & 7.07 & 1.359 & .257 \\
\hline
\end{tabular}

The Table 5 indicated the results of post-test from the experimental class, the average scores were $8.59(\mathrm{SD}=1,991)$, while the average scores for the control class were $7.07(\mathrm{SD}=$ 1,359). Furthermore, the Table 6 showed that the t-test of sig (2-tailed) from the independent sample $\mathrm{t}$-test of post-test was $0.001(\mathrm{p}=<0,05)$; thus, it was significant. This indicated that there was difference in both of classes about the students' metacognitive ability to solve the problems of $K P K$ and $F P B$ after implementing the guided inquiry learning. Departing from these results, it could be concluded that there was a significant effect on the implementation of guided inquiry learning model to improve the students' metacognitive inquiry learning in solving the problems of $K P K$ and $F P B$.

Table 6. The Comparation of Post-Test Scores of Experimental Class and Control Class Score Using the Independent Sample T-Test

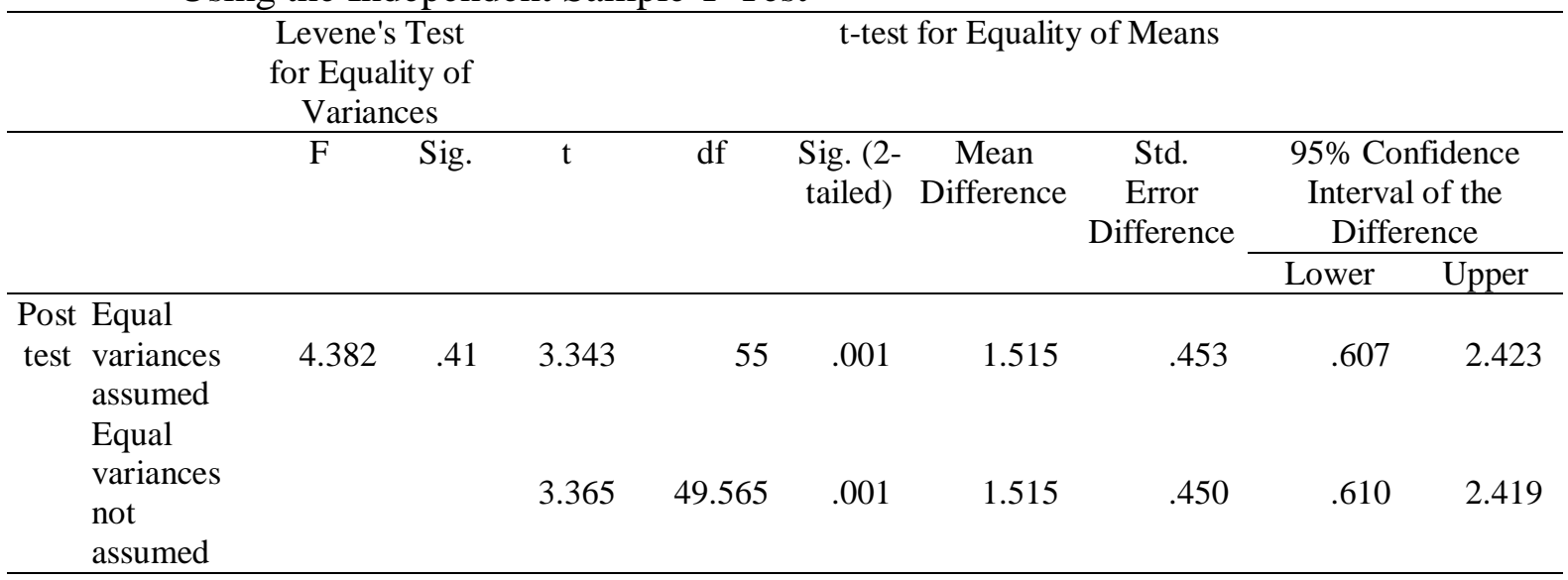

Referring to the students' answer results in solving the problems of $K P K$ and $F P B$, it was obtained the data about the students' metacognitive ability. In the experimental class, the metacognitive activities arose when the students solved the mathematics problems on the material of $K P K$ and $F P B$. The guided inquiry learning encouraged the students to be involved actively in the mathematics learning activities. The guided inquiry learning stages could arise the aspect of metacognitive ability. There were six stages of guided inquiry learning in this study, in which it covered up 1) orientation, 2) problems formulation, 3) hypothesis 
determination, 4) data collection, 5) verification of results/hypothesis testing, and 6) drawing the conclusions

In the orientation stage, the teacher did the apperception and material associating that would be learned before, in which it was about the introduction of multiple and divisor. In this stage, there were several obstacles faced up by the researcher since in the students' initial concept about multiple and divisor material was still low; thus, it needed a hard-working to restimulate previous knowledge. Before going to the material, the students gained information about the basic competencies and learning objectives that would be reached, the scope of the material, the learning stages, and the stages of inquiry learning method. Most of the interaction occurred on the orientation stage was the interaction between the students and the teacher (the researcher), where the activities to prepare the students physically and psychologically through the apperception also could encourage the metacognitive activities. Elbers (2003) also asserted that the interaction in learning of the classroom encouraged the reflection process.

In the problem distribution stage, the students were given the problems in determining the $K P K$ and $F P B$ by means of student worksheets that had been arranged by the researcher. The students were asked to group for 3 to 4 people after the group specified by the teacher and asked them to learn all of the instructions in the worksheet. In this stage, each group was also facilitated by using the learning media of coins. The use of media aimed at assisting the students to introduce the concept of $K P K$ and $F P B$. The guideline of media usage was also listed in the student worksheet. It was in line with a study conducted by Ellwood \& Abrams (2018), the students' interaction especially in group discussions would give each other feedback and increase the students' motivation and achievement results. Hastuti and Sutarto (2017) clarified that primary school students had not been able to think abstractly so that there was a need for learning media to be able to deliver the concepts.

In the stage of preparing the hypothesis, many questioning activities that occurred in the group members, such as the students asking about how to determine the $K P K$ and $F P B$ of two numbers. The students asked one another in their group even the students also asked the teacher. After the students' question, the students would make hypotheses about how to determine the $K P K$ and $F P B$. At this stage, there were several obstacles experienced by the researcher, such as the students' literacy ability that were still lacking, more students asked the teacher than read and found out for themselves. However, the teacher still accustomed the students to read over and over and understand the worksheets that were given from the first meeting to the last so that the students would practice their literacy skills as well. The interactions that occurred at this stage were the interactions between the students and students, the students with the learning resources (student worksheets, textbooks, and coins), and the students and teachers (the researcher themselves), where these interactions encouraged the emergence of metacognitive activities. The metacognitive activities arose, as the students learned to question and evaluate the opinions of peers in groups. It was in line with Chiu \& Kuo's research (2010) which asserted that the social metacognition in group discussions could construct the students' knowledge and strategies so that they could help the students to learn and evaluate the strategies. The student social interactions that occurred in the inquiry learning covered up engaging in discussion, questioning, and analyzing ideas, in which it would increase the motivation and critical thinking (Ellwood \& Abrams, 2018).

Furthermore, in the data collection stage, group one members began to try to determine the $K P K$ and $F P B$ using coins. They also began to answer all questions in the student worksheet. In the observation during this activity, it was found that there were some difficulties experienced by the group, for example the students did not understand the guidelines for using the media on the student worksheets, but the teacher still gave direction so that the students understood and found it themselves. The rest, the students were enthusiastic about this activity and when they felt difficulties, they asked the teacher. Based on the observations and interviews, the students were more enthusiastic about learning since they felt more involved in the activities of fiddling with coins and discussing one another. It was in line with the findings 
of Elbers (2003) that the interactions in inquiry learning would stimulate the students to construct mathematical knowledge and encourage the students to do the reflection process.

Moreover, in the hypotheses testing stage, the students started to re-check whether the hypotheses results made by the students about the determination of $K P K$ and $F P B$ was suitable or not with the experimental results when using the media of coins. There was an interaction in this stage such as the interaction between students and students, the students and learning resources, the students and the teacher, where these interactions encouraged the existence of metacognitive activities. From the finding results, to determine the $K P K$ was by finding out the multiples of each number, finding out the multiples of alliances, and determine the least common multiple. Furthermore, to determine the $F P B$ was by finding out the factors of each number, looking for the common factor, and determine the greatest common divisor. At this stage, the students engaged in metacognitive activities, where the students evaluated, rethought the input from their friends then changed their initial answer. This was consistent with a research conducted by Hurme, Marenluoto, \& Jarvela (2009) that the metacognition arose more when it occurred in group discussions, in which one group member contributed and influenced other members so that other members in the group responded and developed it.

In the conclusion stage, the students concluded that to determine the $K P K$ was by looking for the multiple from each number, looking for the multiples of alliances, and determine the least common multiple. Furthermore, to determine the $F P B$ was by finding out the factors of each number, looking for the common factor, and determine the greatest common divisor. Then, in the reflection stage, the students were asked to describe their difficulties encountered and how to overcome them. Most of the students revealed that they had difficulty in determining the $K P K$ and $F P B$ which were of great value because in this problem it was impossible for them to use coin media. To determine the $K P K$ and $F P B$ which had great value, the students needed to be guided so that they were able to bring concrete things to the abstract (from the use of media to abstract concepts). After being given a teacher's direction, they could conclude how to determine the $K P K$ and $F P B$.

\section{CONCLUSION}

Departing from the data analysis and finding results, it can be concluded that the guided inquiry learning can improve the students' metacognitive ability than the use of conventional method. Each stage of inquiry learning is able to encourage the students' metacognitive activities, especially when the students are involved in a group discussion. The suggestion for further studies is: that the primary school teachers are necessary to implement the guided inquiry learning assisted by media, especially on the mathematics learning. Moreover, for the next researchers, it is suggested to be able to implement the guided inquiry learning using other mathematics topics.

\section{RECOMMENDATION}

The suggestion for further studies is: that the primary school teachers are necessary to implement the guided inquiry learning assisted by media, especially on the mathematics learning. Moreover, for the next researchers, it is suggested to be able to implement the guided inquiry learning using other mathematics topics.

\section{ACNOWLEDGEMENT}

The authors would like to thank the Research and Community Service Institute (LPPM) of Muhammadiyah Mataram University who had funded this study.

\section{REFERENCES}

Biryukov, P. (2014). Metacognitive Aspects of Solving Combinatorics Problems. Journal Mathematic Teaching And Learning, 25(1), 1-19. Retrieved from http://www.cimt.org.uk/journal/biryukov.pdf 
Chiu, M. M., \& Kuo, S.W. (2010). From Metacognition to Social Metacognition: Similarities, Differences, And Learning. Journal of Education Research, 3(4), 321-338. Retrieved from https://www.researchgate.net/publication/291046856

Dorr, L., \& Perels, F. (2019). Improving Metacognitive Abilities As An Important Prerequisite for Self-Regulated Learning in Preschool Children. International Electronic Journal of Elementary Education, 11(5), 449-459. doi: 10.26822/iejee.2019553341.

Elbers, E. D. (2003). Classroom Interaction As Reflection: Learning And Teaching Mathematics In A Community of Inquiry. Educational Studies in Mathematics, 54(2), 77-99. doi: 10.1023/B:EDUC.0000005211.95182.90.

Ellwood, R., \& Abrams, E. (2018). Student's Social Interaction In Inquiry-Based Science Education: How Experiences Of Flow Can Increase Motivation And Achievement. Cultural Studies of Science Education, 13(2), 395-427. doi:10.1007/s11422-016-9769-x

Ergul, R., Simsekli, Y., Calis, S., Ozdilek, Z., Gocmencelebi, S., \& Sanli, M. (2011). The effects of inquiry-based science teaching on elementary school students' science process skills and science attitudes. Bulgarian Journal of Science and Education Policy, 5(1), 48-68. Retrieved from: http://bjsep.org/getfile.php?id=88

Flavell, J. H., Miller, P. H., \& Miller, S. A. (2002). Cognitive Development. New Jersey: Prentice Hall.

Gough, D. (1991). Thinking About Thinking. Alexandria, VA: National Association of Elementary School Principals.

Hastuti, I. D \& Sutarto. (2018). Bahan Manipualtif Dalam Pembelajaran Matematika SD. Mataram: LPP Mandala

Hastuti, I. D., \& Haifaturrahmah. (2018). Analisis Kemampuan Metakognisi Mahasiswa PGSD Dalam Menyelesaikan Masalah Matematika. Jurnal Pendidik Indonesia, 1(2), 103-110.

Hastuti, I. D., Nusantara, T., Subanji., \& Susanto, H. (2016). Constructive Metacognitive Activity Shift in Mathematical Problem Solving. Educational Research and Reviews, 11(8), 656-667. doi: 10.5897/ERR2016.2731

Hayes, M.T. (2002). Elementary Pre-service Teachers' Struggles to Define Inquiry Based Science Teaching. Journal of Science Teacher Education,13(2), 147-165. doi: 10.1023/A:1015169731478.

Hurme, T. R., Marenluoto, K., \& Jarvela, S. (2009). Socially Shared Metacognition of PreService Primary Teachers in a Computer-Supported Mathematics Course and Their Feelings of Task Difficulty: a Case Study. Educational Research and Evaluation, 15(5), 503-524. https://doi.org/10.1080/13803610903444659

Kim, Y. R., Park, M. S., Moore, T. J., \& Varma, S. (2013). Multiple Levels of Metacognition And Their Elicitation Through Complex Problem-Solving Tasks. Journal of Mathematical Behavior, 32(2), 377-396. https://doi.org/10.1016/j.jmathb.2013.04.002

King, F. J, Goodson, L., \& Rohani, F. (1993). Higher Order Thinking Skills. Assessment \& Evaluation Educational Services Program. New York: the Educational Services Program

Kuhlthau, C. C. (2010). Guided inquiry: School libraries in the 21st century. School Libraries Worldwide, 16(1), 1-11. Retrieved from: http://wp.comminfo.rutgers.edu/ckuhlthau/wpcontent/uploads/sites/185/2016/02/GI-School-Librarians-in-the-21-Century.pdf

Kuzle, A. (2013). Patterns of Metacognitive Behavior During Mathematics Problem-Solving in a Dynamic Geometry Environment. International Electronic Journal of Mathematics Education, 8(1), 20-40. Retrieved from: https://www.iejme.com/download/patterns-ofmetacognitive-behavior-during mathematics-problem-solving-in-a-dynamicgeometry.pdf

Margunayasa, I. G., Dantes, N., Marhaeni, A. A. I. N., \& Suastra, I. W. (2019). The Effect of Guided Inquiry Learning and Cognitive Style on Science Learning Achievement. International Journal of Instruction, 12 (1), 737-750. doi: 10.29333/iji.2019.12147a.

Prayitno, B. A. (2011). Pengembangan perangkat pembelajaran IPA Biologi SMP berbasis inkuiri terbimbing dipadu kooperatif STAD serta pengaruhnya terhadap kemampuan 
berpikir tingkat tinggi, metakognisi, dan keterampilan proses sains pada siswa berkemampuan akademik atas dan bawah. Universitas Negeri Malang.

Prayogi, S., Yuanita, L., \& Wasis. (2018). Critical Inquiry Based Learning: A Model of Learning to Promote Critical Thinking Among Prospective Teachers of Physic. Turkish Science Education, 15(1), 43-56. doi: 10.12973/tused.10220a.

Rahmat, I \& Chanunan, S. (2018). Open Inquiry in Facilitating Metacognitive Skills on High School Biology Learning: An Inquiry on Low and High Academic Ability. International Journal of Instruction, 11(4), 593-606. doi: 10.12973/iji.2018.11437a.

Rooney, C. (2012). How am I using inquiry-based learning to improve my practice and to encourage higher order thinking among my students of mathematics. Educational Journal of Living Theories, 5(2), 99-127.

Seraphin, K. D., Philippoff, J., Kaupp, L., \& Vallin, L.M. (2012). Metacognition as means to increase the effectiveness of inquiry-based science education. Science Education International, 23(4), 366-382

Sousa, D. A. (2008). How the Brain Learns Mathematics. Thousand Oaks, CA: Corwin Press. Suastra, I W. (2017). Pembelajaran Sains Terkini: Mendekatkan Siswa dengan Lingkungan Alamiah dan Sosial Budaya Singaraja. Universitas Pendidikan Ganesha.

Suratno, T. (2009). Lesson study in Indonesia: the case of Indonesia university of education. Paper presented at the World Association of Lesson Studies International Conference, Hong Kong Institute of Education, Hong Kong. doi: 10.1108/20468251211256410

Tarrant, P \& Holt, D. (2016). Metacognition in The Primary Classroom. Abingdon: New York Thaiposri P, \& Wannapiroon, P. (2015). Enhancing Students' Critical Thinking Skills Through Teaching and Learning by Inquiry-based Learning Activities Using Social Network and Cloud Computing. Procedia Social and Behavioral Sciences, 17(4), 2137-2144. doi: 10.1016/j.sbspro.2015.02.013

Towers, J. (2010). Learning to teach mathematics through inquiry: a focus on the relationship between describing and enacting inquiry-oriented teaching. Journal of Mathematics Teacher Education, 13(3), 243-263. doi: 10.1007/s10857-009-9137-9.

Van der Stel, M., \& Veenman, M. V. J. (2014). Metacognitive skills and intellectual ability of young adolescents: A longitudinal study from a developmental perspective. European Journal of Psychology of Education, 29(1), 117-137. https://doi.org/10.1007/s10212013-0190-5

Winne, P., \& Hadwin, A. (2008). The weave of motivation and self-regulated learning. In D.H., Schunk \& B.J., Zimmerman (Eds.), Motivation and self-regulated learning: Theory, research, and applications (pp. 297-314). Mahwah, NJ: Erlbaum.

Wismath, S., Orr, D., \& Good, B. (2014). Metacognition: Student Reflections on Problem Solving. Journal on Excellence in College Teaching, 25(2), 69-90.

Zohar, A., Degani, A., \& Vaaknin, E. (2001). Teachers' beliefs about low-achieving students and higher order thinking. Teaching and Teacher Education, 17(4), 469-485. doi: 10.1016/S0742-051X(01)00007-5 